\title{
Malnutrition and impaired immune response to infection
}

\section{By Hylton McFarlane, University of Manchester Medical School, Oxford Road, Manchester $M_{1} 39 P$}

The partnership of ignorance, poverty, infections and malnutrition has become so firmly entrenched in many parts of the southern hemisphere that sociologists and economists have been tempted to ascribe a genetic basis to it (Fig. r). Wherever you encounter the one, the others are sure to be there, not just lurking in the shadows but distinctly apparent everywhere.

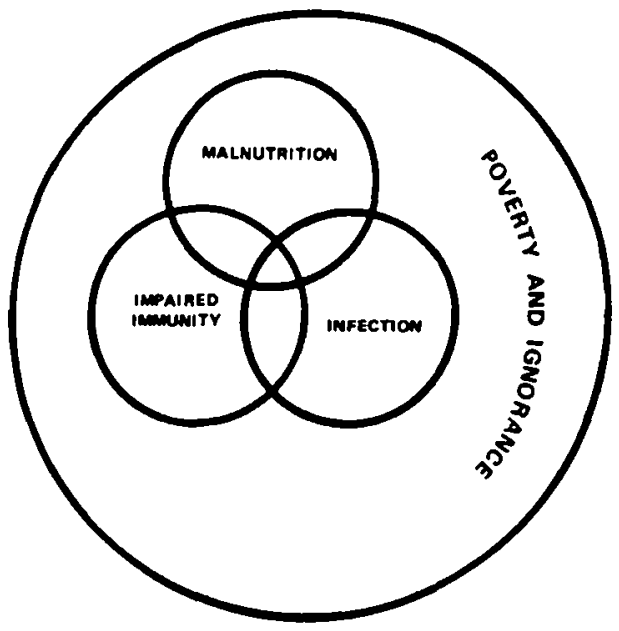

Fig. 1. Relationship between infection, immunity and malnutrition.

It must be emphasized at the outset, however, that infection alone is quite capable of initiating an impaired immune response as well as frank kwashiorkor. This frequently occurs following a severe attack of measles in the African child (Morely, 1967).

\section{Infection and malnutrition}

Measles is now regarded as a minor illness in schoolchildren in the northern hemisphere. However, it accounts for over 100000 deaths/year in Nigerian children before they reach school age, (Smith \& Foster, 1970). The case fatality in several parts of Africa is of the order of seven deaths/rooo (Morley, Katz \& Krugman, 1963). Savage (1970) noted that measles is probably the commonest single cause of death among children in Zambia, confirming what several others 
had previously observed, that measles is the most lethal of the diseases experienced by the pre-school child on the African continent.

In the African, foetal immunoglobulin $\mathrm{G}(\mathrm{IgG})$ is less than maternal IgG, which is in contrast to Europeans. Beast-feeding is thought to confer passive immunity to the young child, and although breast-feeding by African mothers may continue for as long as 23 months, the amount of protective antibody which the child receives from its mother is not great because, even though the composition is similar to that of the European counterpart, the volume of maternal milk produced is significantly less (Edozien, 1965).

It is little wonder, therefore, that not only measles, which has a peak age incidence of 12 months in the African child, but also smallpox and other viral infections have an early peak age incidence, occurring at a time when the child of the tropics is least resistant to infection. Carey, Reddy, Causey, Akinkugbe, DavidWest, Moore \& Cooke (1970) have estimated that $38 \%$ of the febrile illness in the Nigerian child is due to some form of viral infection. This is also true of his counterpart in Central and South America, the Caribbean and Asia.

Weanling diarrhoea is a well-recognized epidemiological entity in most underdeveloped countries. Gastroenteritis among infants is due primarily to viral infection and secondarily to organisms like Escherichia coli which are usually nonpathogenic in well-nourished populations. However, in Mexico City, RamosAlvarez \& Olarte (1964) isolated adenovirus and echovirus about ten times more frequently in diarrhoeal diseases than in non-diarrhoeal diseases in young infants. Wadström (1975) observed that the practice of early weaning of babies in Trinidad is more than likely to be responsible for these epidemics of infantile gastroenteritis.

Tetanus neonatorum is of major public health concern in several parts of Africa, where the case fatality may be as high as $96 \%$. Jelliffe (1950) and Williams (1970) noted that there was a striking correlation between the incidence of neonatal tetanus and a low socioeconomic status of the parents, implying that both poverty and ignorance are more than likely to be at the root of this problem.

In a recent study conducted among Nigerian preschool children in a rural area, 95\% of them suffered from Ascaris; $30 \%$ from Strongyloides; $47 \%$ from Trichuris; $60 \%$ from Plasmodium falciparium and $12 \%$ from Entamoeba histolytica. This burden of infestations and infections helps to create a cycle of events which leads to protein-energy malnutrition (PEM), a depressed immune response, and constant infections, a fate to which many such children of the tropics are doomed.

\section{Maternal-foetal infection and the effect of malnutrition on the immune response}

In several studies in both African and West Indian populations, the ratio, maternal: foetal serum IgG was above $1 \cdot 0$, whereas in European populations it was less than $\mathrm{I} \cdot 0$; it is possible that catabolism by the foetus of IgG derived from the mother occurs earlier and to a greater extent in tropical than in temperate regions. There was also an increased frequency of positive C-reactive protein in both 
maternal and foetal sera of African and West Indian populations, and in foetal sera there was a disproportionately high concentration of immunoglobulin $M$ (IgM), confirming that some form of infection had occurred while the child was in utero (McFarlane, 1966; Michaux, Heremans \& Hitzig, 1966; McFarlane \& Udeozo, 1968; McFarlane, Talerman \& Steinberg, 1970).

Thus, even before delivery, the child of the tropics is likely to encounter a hostile environment. It is of some significance also that $97 \%$ of children with PEM have parents who cannot read or write. The child of the tropics is further subjected after birth to a variety of viral and bacterial infections before he learns to walk, and after learning to walk is confronted with these in addition to a multitude of parasitic infestations, which in themselves can cause undernutrition and an impaired immune response.

PEM is frequently precipitated by an attack of measles, largely owing to the severe negative nitrogen balance and marked impairment of the immune response generated by the virus. Osunkoya, Oyediran \& Cooke (1973) reported an abnormal phytohaemagglutinin (PHA) response and multinucleated giant cells in 3 -d-old leukocyte cultures from children with measles.

An episode of acute infection or malnutrition or both in children is known to create an alarm reaction which sets in motion a sequence of events leading to the stimulation of the pituitary-adrenal axis and increased production of glucocorticoids one of whose target organs is the thymolymphatic system. When, therefore, these conditions occur during gestation their effects upon the immune response of the foetus are long-lasting or may even be permanent. Adlard, Hamid, Labedz \& McFarlane (1973) have shown that growth retardation during foetal and suckling periods resulted in high rates of $\left[{ }^{3} \mathrm{H}\right]$ corticosterone uptake into spleen and thymus and depressed immune function. Nutritional thymic hypotrophy is reversible when the malnutrition occurs after I year of age. When it occurs at an earlier age or in utero this damage to the thymus is likely to be irreversible. Not only is the thymus affected, but also and particularly the deep cortical areas of the lymph nodes and the perivascular area of the white pulp of the spleen, where $T$ cells (lymphocytes of thymus origin) are situated.

\section{T-cell function}

The thymolymphatic atrophy and absolute decrease in total lymphocyte population caused by malnutrition exhibits itself as a most pronounced suppression of T-cell functions in vivo and in vitro. There is (a) decrease in the number of $E$ rosettes formed with sheep erythrocytes; (b) impairment of the PHA response; (c) impairment of delayed hypersensitivity to T-cell-dependent antigens; (d) negative Heaf test; (e) a decrease in lymphokine production; (f) an impairment of a 'helper cell' function and (g) impairment of phagocytic killing.

The abnormalities are significantly more severe when there is concomitant infection. The decrease in the numbers of $\mathrm{T}$-cell rosettes has a high correlation with the extent and severity of the malnutrition. Although in the mildly malnourished child there was a return to normal values of T-cells after $6-9$ weeks 
of refeeding, malnourished children who had developed their disease before the age of 12 months and those with very severe kwashiorkor had a more sustained diminution of $\mathrm{T}$-cell numbers (Fig. 2).

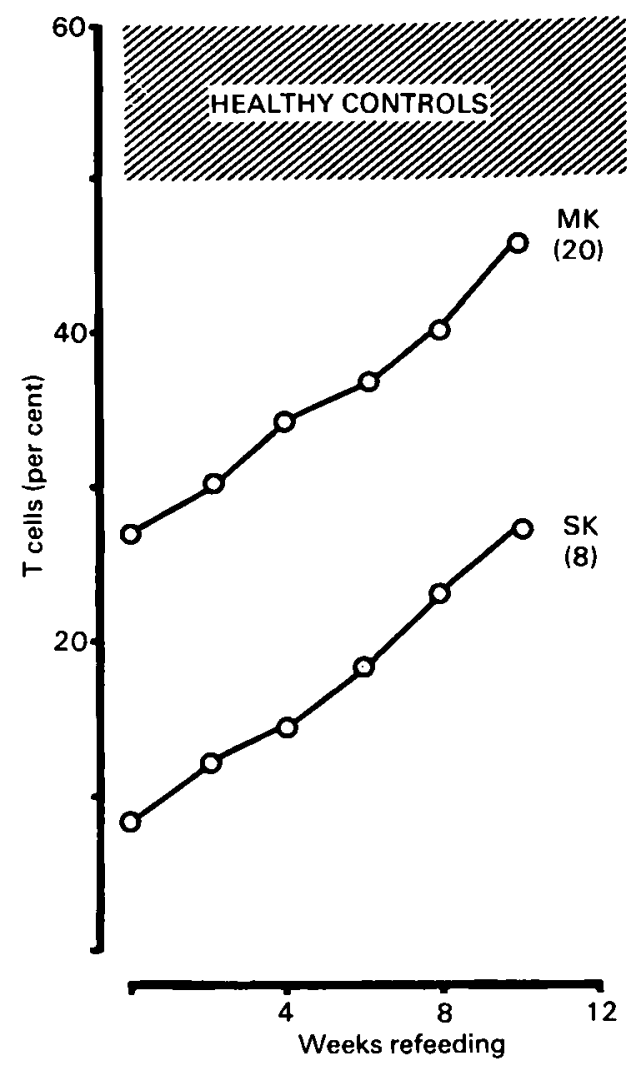

Fig. 2. Mean T-cell rosette formation in healthy controls, and in patients with moderate kwashiorkor (MK) and severe kwashiorkor (SK) before and during refeeding.

These results are similar to those of the PHA transformation and the Heaf test (McFarlane, Reddy, Adcock, Adeshina, Cooke \& Akene, r970; McFarlane \& Hamid, 1973), which return to normal after about 6 months of refeeding but after the biochemical abnormalities had already done so.

The cutaneous delayed hypersensitivity response to several antigens including dinitrochlorobenzene, dinitrofluorobenzene and Candida albicans are noticeably diminished. Edelman, Suskind, Olson \& Sirisinha (1973) have emphasized that up to $80 \%$ of children with PEM on admission to hospital had impaired function of both the afferent limb of their immune response and their cutaneous inflammatory response, although these were corrected after nutritional recovery. These results have been confirmed in experimental animals which had different grades of protein deprivation. During the primary immune response in malnourished rats the direct plaque-forming cells (PFC) and rosette-forming cells (RFC) in the spleen, thymus and bone marrow were profoundly depressed. However, during the primary 
response the percentage reduction of RFC was far greater than that of the PFC, although in the secondary response the reverse occurred (McFarlane \& Hamid, 1973). In malnourished animals the number of RFC in the spleen and thymus returned to normal, but did so significantly later than did PFC, indicating greater impairment of $\mathrm{T}$-cell function than of B-cell (lymphocytes of bone-marrow origin) function in malnourished populations. In addition, there is a much greater percentage of non-reactive 'null' cells in children with PEM than in age-matched controls.

T-cell function is so sensitive to the effects of malnutrition that even in marginally undernourished adults there is distinct impairment of the in vivo delayed hypersensitivity test (Law, Dudrick \& Abdou, 1973; Harrison, Tugwell \& Fawcett, 1975).

\section{B-cell function}

There is overwhelming evidence that the concentration of serum immunoglobulins in malnutrition is normal or raised when there is concomitant infection (McFarlane, 1966). Furthermore, in weanling rats given isoenergetic diets with 180,50 , Io and $5 \mathrm{~g}$ protein $/ \mathrm{kg}$, the serum IgG concentration was elevated in the groups given the diets with 50 , 10 and $5 \mathrm{~g}$ protein $/ \mathrm{kg}$. These groups also had apparent infections as judged by bacterial cultures and clinical observations (Fig. 3).

In most protein-energy malnourished children, but with the exception of those with the severest form of kwashiorkor, the percentage of B-cell rosettes was normal (Fig. 4) in contrast to T-cell rosettes which are reduced in both mild and severe PEM.

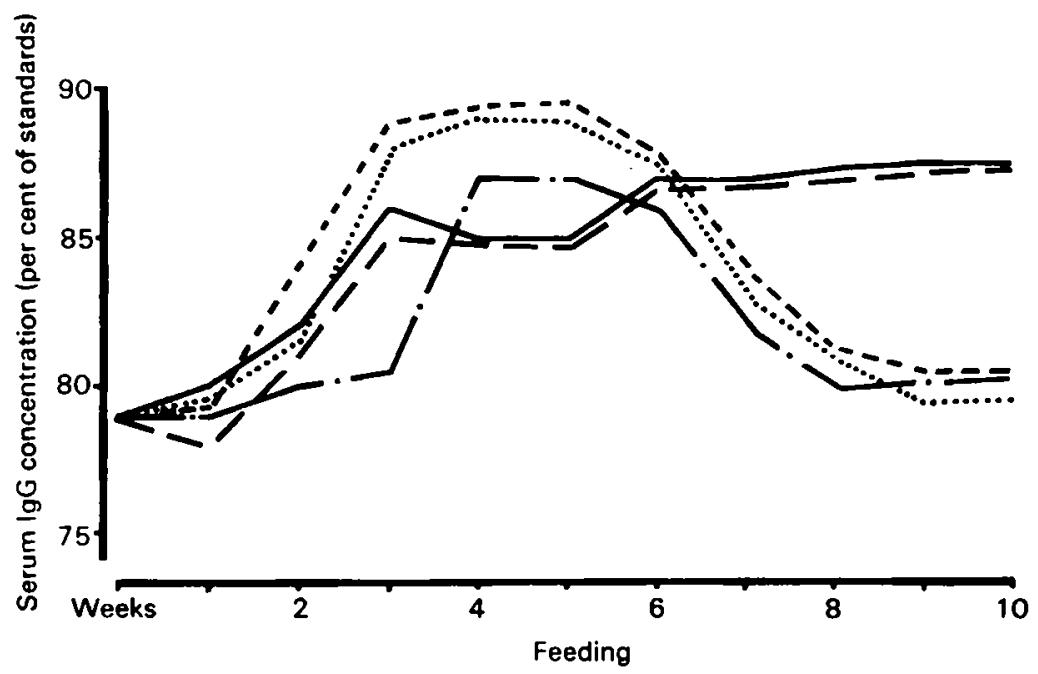

Fig. 3. Serum IgG concentrations in rats fed an isocaloric diet with different concentrations of protein (\%): - —, $18 ;-\cdots, 5 ; \cdots, 1 ;---, 0.5 ;-$, control. 


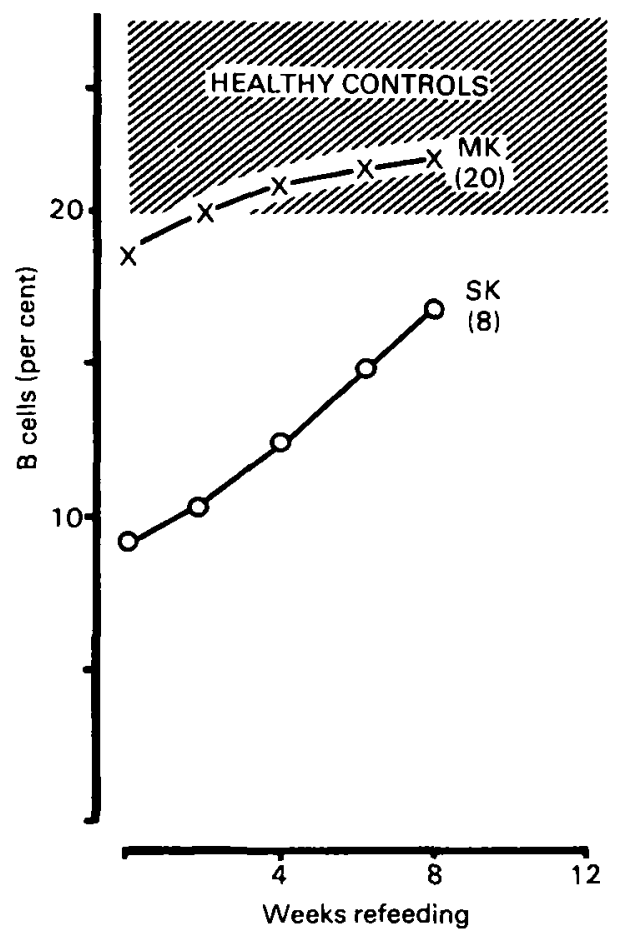

Fig. 4. Mean B-cell rosette formation in healthy controls, and in patients with moderate kwashiorkor $(x)$ and severe kwashiorkor $(O)$ before and during refeeding.

The markedly elevated serum IgM in cord blood and the increased maternal:foetal IgG ratio in tropical populations appear to be a direct result of intrauterine infections (McFarlane \& Udeozo, 1968).

\section{Specific antibodies}

The production of specific antibodies in the malnourished host is usually impaired depending upon the antigen and on the severity of the disease, (Gell, 195I; Olarte, Cravioto \& Campos, r 956). Four Nigerian children who had evidence of malnutrition before the age of I year had a depressed serum IgG production which continued for a period of 12 months.

It would seem that in PEM the production of specific antibody to those antigens which require cooperation between $T$ - and B-cells is impaired, whereas those which do not require such cooperation will not be affected. For instance Nigerian children with severe kwashiorkor had increased circulating heterophile antibodies and rheumatoid factor but decreased measles antibodies, which on refeeding returned to normal values (Awoinfa, Batubo, McFarlane, Reddy \& Salimonu, I97I). This conclusion is supported by observations in experimental animals. Growth-retarded, undernourished suckling rats had a long delay in the maturation of their specific antibody-producing cells as measured by total numbers of PFC (Adlard et al. 1973). 
Secretory immunoglobulin $A$ (SIgA)

Although the serum IgA concentration may be perfectly normal there is an increased frequency of the SIgA abnormality in the gastrointestinal juices of children with gastroenteritis and marasmus. Some of these children had either a complete absence of secretory component (SC) or of SIgA or of both from their gastrointestinal juices, or the presence of excess free J-chain, indicating that abnormalities in the assembly and synthesis of the molecules may be partly responsible for the raised serum $\operatorname{IgE}$ and the frequent diarrhoea in malnutrition (Wallwork, Brenchley, McCarthy, Allan, Moss, Ward, Holzel, Williams \& McFarlane, 1974).

\section{Immunoglobulin E (IgE)}

Passive cutaneous anaphylaxis carried out in the baboon skin as well as specific IgE determination revealed that the markedly elevated serum total IgE in the malnourished child is due to: helminth infestation, grass pollen, Schistosoma, $E$. histolytica and house-dust mite, indicating that the IgE antibody has some functional activity in the malnourished child (Table $r$ ). Failure of the $\operatorname{IgE}$ concentration to return to normal after refeeding, even when most of the other indices of malnutrition including thymus function had done so, indicated that it was the infection and not the protein deprivation which was responsible for the sustained level of IgE. Furthermore that there was no relationship between the serum IgE concentration and T-cells.

Table I. Passive cutaneous anaphylaxis (PCA) reactions in the baboon skin*

Diagnosis

\begin{tabular}{|c|c|c|c|c|}
\hline \multicolumn{5}{|c|}{ Allergen } \\
\hline Ascaris & $\begin{array}{l}\text { Grass } \\
\text { pollen }\end{array}$ & Schistosoma & $\begin{array}{l}\text { Entamoeba } \\
\text { histolytica }\end{array}$ & $\begin{array}{l}\text { Dermatophagoides } \\
\text { pteronyssinus }\end{array}$ \\
\hline $\begin{array}{cc}\text { No. } & \% \\
\text { tested } & (+)\end{array}$ & $\begin{array}{c}\text { No. } \% \\
\text { tested }(+)\end{array}$ & $\begin{array}{cc}\text { No. } \% \\
\text { tested }(+)\end{array}$ & $\begin{array}{cc}\text { No. } & \% \\
\text { tested } & (+)\end{array}$ & $\begin{array}{l}\text { No. } \\
\text { tested }\end{array}$ \\
\hline
\end{tabular}

Protein-energy

malnutrition

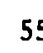

55

$55 \quad 53$

47

41

42

$12 \quad 25$

43

35

Control

(Nigerians)

$\begin{array}{lll}33 & 42 & 33\end{array}$

33

$33 \quad 28$

$-\quad-$

33

15

Asthma

(British)

$55-49$

56

-PCA reaction after $0.1 \mathrm{ml}$ of serum was injected subcutaneously in the baboon's skin. After $18 \mathrm{~h}, 3 \mathrm{ml}$ of $2 \%$ Evans blue and $40 \mathrm{mg} / \mathrm{ml}$ of the antigen were injected intravenously. Positive specimens gave a distinct blue coloration of the baboon skin within $5 \mathrm{~min}$ due to extravasation of the dye.

\section{Serum complement components}

With the exception of components $\mathrm{C}_{4}$ and $\mathrm{C}_{5}$, those children with the severest form of malnutrition and those which had apparent infections had the most 35 (3) 2 
pronounced suppression of their complement components (Fig. 5). Within $2 \mathrm{~d}$ of refeeding the children with a high-protein diet there was a significant increase in the serum $\mathrm{C}_{3}$ concentration, even before the transferrin concentration had risen. Furthermore, the abnormal serum immunoelectrophoretic pattern which originally showed increased $\mathrm{C}_{3}$ utilization had disappeared by the $4^{\text {th }}$ day of refeeding.

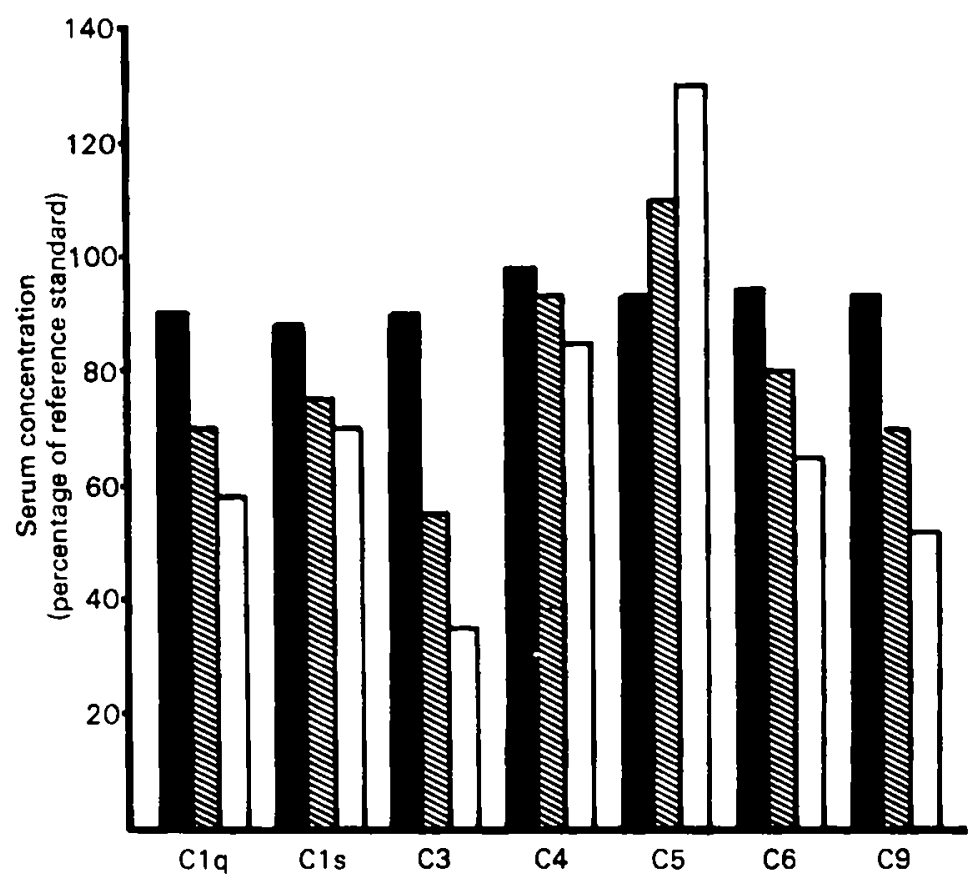

Fig. 5. Serum complement component concentrations in healthy controls $(\square)$, and in patients with kwashiorkor $(\square)$ and with marasmus ( $\mathbb{Q})$.

\section{Non-specific factors and infection in malnutrition}

The increased infection encountered in malnutrition is responsible for the increased synthesis of $\mathrm{C}$-reactive protein and it is noteworthy that soon after successful treatment gets underway the C-reactive protein usually returns to normal.

The serum transferrin plays an important part in helping to prevent infections by its capacity to bind serum iron. When, however, it becomes markedly reduced, as in the malnourished child, and its saturation with $\mathrm{Fe}$ is complete, any $\mathrm{Fe}$ that is given to such a malnourished individual may remain free in the circulation so that it could enhance bacterial growth and consequently infections of the host. Transferrin has an inverse relationship with ferritin, which seems to behave as an acute-phase protein in malnutrition (Fig. 6). Fortunately, transferrin has a rapid turnover and within 2-3 d of refeeding the malnourished child with a high-protein diet, the transferrin concentration is usually well on its way to returning to normal levels (McFarlane et al. 1970). 


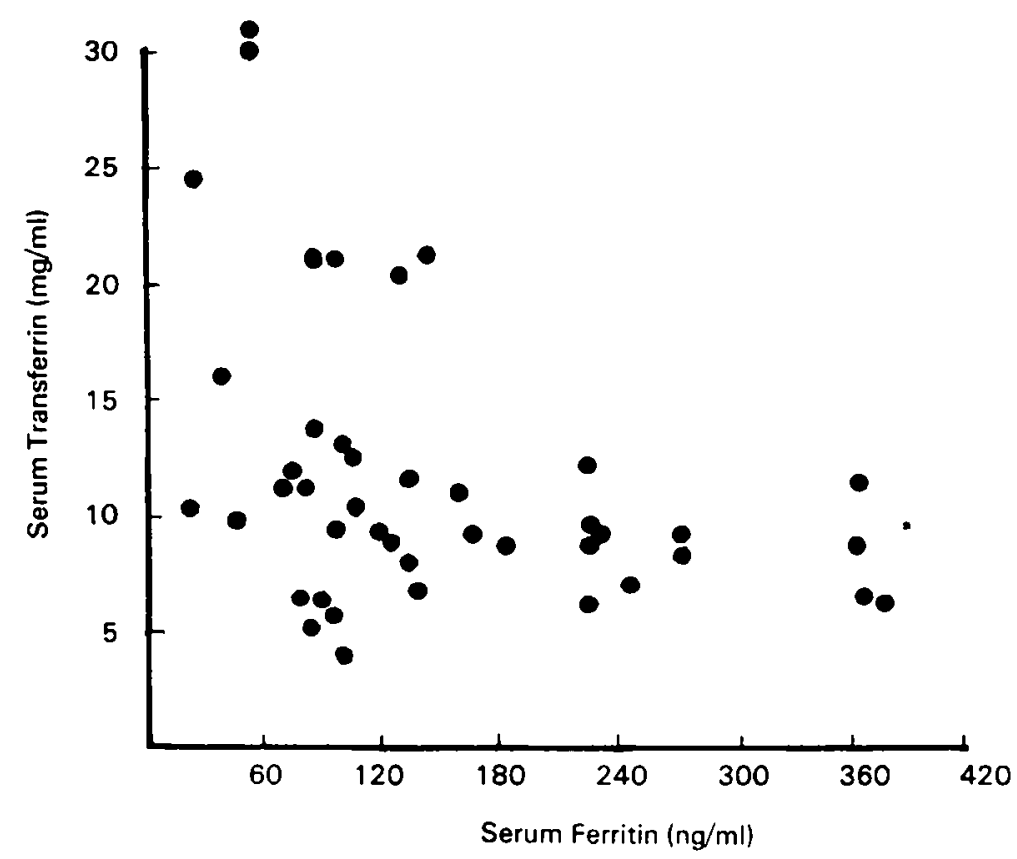

Fig. 6. Inverse relationship between serum transferrin and serum ferritin in female patients with kwashiorkor: $r-0.37, P=0.025-0.05$.

\section{Summary}

The cycle of events which leads to an impairment of the immune response in the malnourished child includes poverty, food deprivation and frequent infections. It is of great significance, however, that the marked suppression of the immune response can be repaired reasonably promptly, if the disease commences after the child has attained I year of age. Prenatal infection not only generates growth retardation but also a higher maternal to foetal IgG ratio, higher IgM in the neonate and a sustained immune depression. Passive cutaneous anaphylaxis measurements in the baboon skin and specific $\operatorname{IgE}$ determinations reveal that the elevated IgE in PEM is due to parasitic infestation and common allergens and has little or no relationship with decreased $\mathrm{T}$-cell function.

\section{REFERENCES}

Adlard, B. P. F., Hamid, J., Labedz, R. \& McFarlane, H. (1973). Pediat. Res. 7, 883.

Awoinfa, J. D., Batubo, T. A., McFarlane, H., Reddy, S. \& Salimonu, L. S. (1971). Afr. F. med. Sci. 2, 49 .

Carey, D. E., Reddy, S., Causey, O. R., Akinkugbe, F. M., David-West, T. S., Moore, D. L. \& Cooke, A. R. (1970). Bull. int. epidem. Ass. 20, 73.

Edelman, R., Suskind, R., Olson, R. E. \& Sirisinha, S. (1973). Lancet i, 506.

Edozien, J. C. (1965). $Y l W$. Afr. Sci. Ass. $11,22$.

Gell, P. G. H. (195I). Spec. Rep. Ser. med. Res. Coun. no. 275 , p. 193.

Harrison, B. D. W., Tugwell, P. \& Fawcett, I. W. (I 975). Lancet i, 42 I. 
Jelliffe, D. B. (1950). Archs Dis. Childh. 25, 190.

Law, D. K., Dudrick, S. J. \& Abdou, N. I. (1973). Ann. intern. Med. 79, 545.

McFarlane, $H$. (1966). Lancet i, 445 .

McFarlane, H. \& Udeozo, I. O. K. (1968). Archs Dis. Childh. 43, 42.

McFarlane, H., Talerman, A. \& Steinberg, A. G. (1970). f. clin. Path. 23, 124.

McFarlane, H. \& Hamid, J. (1973). Clin. exp. Immunol. 13, 153.

McF arlane, H., Reddy, S., Adcock, K. J., Adeshina, H., Cooke, A. R. \& Akene, J. (1970). Br. med. 7. iv, 268.

Michaux, J. L., Heremans, J. F. \& Hitzig, W. H. (1966). Trop. geogr. Med. 18, to.

Morley, D. (1967). Modern Trends in Virology, p. I4I. London: Butterworth.

Morley, D., Katz, S. L. \& Krugman, S. (1963). f. Hyg., Camb. 6r, 135.

Olarte, J., Cravioto, J. \& Campos, B. (1956). Boln méd. Hosp. infant., Mex. 13, 467.

Osunkoya, B. O., Oyediran, A. B. O. \& Cooke, A. (1973). Immunology 25, 737 .

Ramos-Alvarez, M. \& Olarte, J. (1964). Am. Y. Dis. Child. 107, 218.

Savage, F. M. A. (1970). Bull. int. epidem. Ass. 20, 29.

Smith, E. A. \& Foster, S. O. (1970). Bull. int. epidem. Ass. $20,17$.

Wadström, T. (1975). Paper read at XIII Swedish Nutrition Foundation Symposium, Sweden.

Wallwork, J. C., Brenchley, P., McCarthy, J., Allan, J. D., Moss, D., Ward, A. M., Holzel, A., Williams, R. F. \& McFarlane, H. (1974). Clin. Exp. Immunol. 18, $3 \circ 3$.

Williams, G. A. (1970). Bull. int. epidem. Ass. 20, 63. 